\title{
Biochemical analysis of cyanobacterial strains isolated from different Tunisian inland waters: therapeutical and nutritional potential
}

\author{
Khaled GHARBI $^{1 *}$, Afef FATHALLI ${ }^{2}$, Chiheb FASSATOUI ${ }^{1}$, \\ Mohamed Salah ROMDHANE ${ }^{1}$ and Amel Ben Rejeb JENHANI ${ }^{1}$
}

${ }^{1}$ Unité de Recherche Écosystèmes et Ressources Aquatiques (UR13AGRO1), Institut National Agronomique de Tunisie, University of Carthage, 43, avenue Charles Nicolle, 1082 Tunis Mahrajène, Tunisia.

${ }^{2}$ Institut National des Sciences et Technologies de la mer, Port de pêche 2060, La Goulette, Tunisia. *Corresponding author; E-mail: khaledgharbi10@yahoo.fr; Tel: (00216) 29431014

\begin{abstract}
The last decade period has been characterized by a remarkable increase in the need for food, bioenergy, and pharmaceutical compounds. Meanwhile, microalgae have been in the center of interest as a rich and sustainable source of highly valuable natural products and bioactive compounds. In this perspective, the present study aimed at investigating the biochemical composition of 10 cyanobacterial strains collected from several Tunisian inland waters, seeking to identify the possible use of cyanobacteria in nutraceuticals and pharmaceuticals industry, and for animal and human consumption. Ten local strains of cyanobacteria were isolated from several Tunisian inland waters and cultured in controlled laboratory conditions. Fatty Acid methyl esters were analyzed in each strain by Gas chromatography-Mass spectrometry (GC-MS) as well as total proteins, carbohydrates and different phycobiliproteins (phycocyanin, allophycocyanin and phycoerythrin). Results showed that Planktothrix agardhii, Leptolyngbya sp1., and Leptolyngbya sp2. contained 14 different fatty acids, among which oleic acid was the most abundant. These might be important in nutraceutical and agronomic sectors due to the potent antioxidant and larvicidal activities of oleic acid. Cylindrospermopsis raciborskii presents extraordinarily high levels of phycocyanin, making it an exceptional natural reservoir of effective and non-toxic drugs that are of particular interest against cancer and neurodegenerative diseases. Extracts from cyanobacterial strains represent a natural and available source of proteins, of highly valuable fatty acids, and especially of phycocyanin which is known by its extremely health beneficial properties. The nutritional and functional complements provided by these extracts can be used in the prevention of various diseases and also as effective and environmentally friendly insecticides.
\end{abstract}

(C) 2019 International Formulae Group. All rights reserved.

Keywords: Cyanobacteria; biochemical composition; fatty acids; phycobiliproteins; valorization.

\section{INTRODUCTION}

Photoautotrophic

microscopic organisms include a large variety of species of widespread occurrence and with diverse morphological, physiological, and biochemical properties (Kata et al., 2018). Among these organisms, cyanobacteria occupy all types of habitats as they are able to overcome a plethora of environmental constraints, including cold, drought, salinity, photo-oxidation, anaerobiosis, osmotic pressure, and exposure to UV radiations (Samarakoon and Jeon, 2012; Moscoso et al., 2013). Furthermore, recognized as important 
primary producers, cyanobacteria are major actors in the aquatic food chain, playing significant roles in carbon, nitrogen, and oxygen biochemical cycles (Moscoso et al., 2013).

Considering the increasing need for food, feeding, bioenergy, and pharmaceutical compounds, particular attention has been paid during the last decade to microalgae as a sustainable natural source of biologically active compounds that do not compete with the usual food resources. In particular, cyanobacteria have gained interest for producing third generation biofuels (both biomass and $\mathrm{H}_{2}$ production) as well as for being valued in various fields, especially in agro-food, aquaculture, biotechnology, and pharmacy (Trabelsi et al., 2017). For example, cyanobacterial protein has received worldwide attention both as a food supplement and as an alternative source of food. Some species of Anabaena, Nostoc, and Arthrospira are consumed as food due to their high protein and fiber content (Plaza et al., 2009). The cyanobacterium Arthrospira platensis exhibits extremely high protein content (up to 85.5\% of dry weight) (M'baye et al., 2011).

Furthermore, phycobiliproteins are among the most valuable accessory pigments that can be extracted from cyanobacteria, given their extremely health beneficial effects. These water-soluble, fluorescent proteins are largely considered as potent functional ingredients with very interesting applications in various fields, especially in biotechnology, medicine, and pharmacy (Jalal et al., 2013).

Therefore, the present research aimed at sampling, identifying, and characterizing 10 cyanobacterial strains collected from several Tunisian inland waters. Their biochemical composition (fatty acids, proteins, and carbohydrates) as well as their phycobiliprotein constituents (phycocyanin, allophycocyanin, and phycoerythrin) were determined with the purpose of identifying the cyanobacterial strains' possible use in nutraceuticals, pharmaceuticals, animal feed, and even as human food.

\section{MATERIALS AND METHODS}

\section{Cyanobacteria strains: isolation and culture}

Cyanobacteria strains were isolated from seven different Tunisian inland waters (river, lagoon, dam reservoir, spring water) located in northern, central and southern Tunisia (Table 1, Figure 1). The strains (Chroococcus sp.: Chroo-CH, A. platensis: Arthro-KB, Leptolyngbya sp1.: Osci-NB-01, Leptolyngbya sp2.: Lepto-CH, Limnothrix sp.: Osci-BM-01, Planktothrix agardhii: PlankSS-01, Spirulina sp.: Spir-ML, Lyngbya sp.: Lyng-ML, Anabaenopsis circularis: Pseud-01, Cylindrospermopsis raciborskii: Cyl-NB-05) were isolated in the laboratory by capillary isolation on liquid medium and observed using an inverted microscope (Leica microsystems, Wetzlar, Germany). For each strain, isolation was performed on a single individual (a single cell, a colony or a filament) in $300 \mu \mathrm{l}$ of appropriate culture medium and the growing was carried out by scaling-up culture volumes gradually from the initial isolation to the final batch. All strains were cultivated in $2 \mathrm{~L}$ volume laboratory flasks using monospecific batch culture system under sterile conditions. Each strain was cultured in either BG11 (Rippka et al., 1979) or CONWAY (Blancheton, 1985) culture medium depending on the origin of each strain (Table 1). Culture media were sterilized by autoclaving at $120{ }^{\circ} \mathrm{C}$ for 20 minutes before use. The cultures were incubated at $25 \pm 1{ }^{\circ} \mathrm{C}$ in a thermostatically controlled room and illuminated with cool white fluorescent tubes at an intensity of 2000 lux (approximately $10 \mu \mathrm{mol} \mathrm{m} \mathrm{m}^{-2} \mathrm{~s}^{-1}$ ) in a $16: 8$ h light: dark regime. Each culture was stirred continuously with air at a low and constant flow rate. The period of cultivation was from 8 to 26 days and the cells were harvested by centrifugation (3000 rpm for 10 minutes) and lyophilized using a Christ Alpha 2-4 LD Plus freeze-92 dryer (Harz, Germany). The freezedrying operation was carried out under vacuum at $-70{ }^{\circ} \mathrm{C}$ and for 2 days long. For all biochemical analysis (fatty acids, proteins, carbohydrates, and phycobiliproteins), each 
culture was sampled in the exponential growth phase only.

\section{Molecular identification}

Total genomic DNA was extracted from fresh cells harvested by centrifugation during the exponential growth phase of each strain using the DNeasy ${ }^{\circledR}$ Plant Mini Kit (QIAGEN GmbH, Hilden, Germany) and following the protocol for Gram-negative bacteria as recommended by the manufacturer. The DNA was subsequently kept frozen at $-20{ }^{\circ} \mathrm{C}$ until use. DNA extracts were checked by electrophoresis in a $1 \%$ agarose gel. The DNA was quantified with a Thermo Fisher Scientific spectrometer (Massachusetts - USA) and subsequently diluted to $200 \mathrm{ng} / \mu \mathrm{L}$ solution.

Nuclear-encoded 16S rRNA gene segments were amplified with PCR primers $27 \mathrm{FW}$ and $1494 \mathrm{Rev}$ under conditions described by (Fathalli et al., 2011). All PCR amplifications were performed in $20 \mu \mathrm{L}$ aliquots containing $10 \mathrm{pmol}$ of each forward and reverse primers (Invitrogen, Carlsbad, California), 1x Reaction Buffer (Invitrogen, Carlsbad, California), $250 \mu \mathrm{M}$ of each deoxynucleosides triphosphate (OMEGA biotec TQAC136), $2.5 \mathrm{mM} \mathrm{MgCl} 2$ (Invitrogen, Carlsbad, California), 0,5 U of Taq DNA polymerase (Invitrogen, Carlsbad, California) and 5 to $10 \mathrm{ng}$ of genomic DNA template. All PCR amplicons were analyzed by electrophoresis in 1\% agarose gel (Invitrogen, Carlsbad, California) run in $1 \times$ TBE buffer, stained with ethidium bromide and photographed under UV trans-illumination.

A total of $100 \mu \mathrm{L}$ of PCR of each amplified product was purified using a PureLink $^{\circledR}$ PCR Purification Kit (Invitrogen, Carlsbad, California) following the protocol supplied by the manufacturer before being sent for direct sequencing. Nucleotide sequences were obtained and submitted to the (Basic Local Alignment Search Tool) BLAST database

(http://www.ncbi.nlm.nih.gov/BLAST) for identification.
All sequences were subsequently submitted to the GenBank database (accession numbers are given in Table 2).

\section{Fatty acids analysis}

For each strain, after lipid extraction using a mixture of dichloromethane: methanol: $0.7 \%$ aqueous $\mathrm{NaCl}(1: 2: 0.8, \mathrm{v} / \mathrm{v} / \mathrm{v})$ according to a method adapted from (Bligh and Dyer, 1959). Samples were then derivatized with $1 \mathrm{~mL}$ of $7 \%$ boron trifluoride in methanol $\left(\mathrm{BF}_{3}-\mathrm{MeOH}\right)$ and $1 \mathrm{~mL}$ of toluene (100 ${ }^{\circ} \mathrm{C}$ for 60 minutes) according to a method adapted from (Morrison and Smith, 1964) to prepare Fatty Acid methyl esters (FAMEs). After heating, $2 \mathrm{~mL}$ of distilled water were added and samples were centrifuged at $3000 \mathrm{rpm}$ during 4 minutes. The organic layer was separated and the aqueous layer was extracted three times with 1 $\mathrm{mL}$ of toluene. The obtained Fatty Acid Methyl Esters (FAMEs) were then analyzed by GC-MS (Gas chromatography-mass spectrometry) on a ThermoQuest trace GC/Thermo ITQ 900, ion trap mass spectrometer run with the Xcalibur 2.1 software package. The Electron Ionization method was used at $70 \mathrm{eV}$. FAMEs were separated on a Thermo TG-5MS column (30 $\mathrm{m}$ long, $0.25 \mathrm{~mm}$ i.d., $0.25 \mu \mathrm{m}$ film thickness). The temperature program was as follows: initial, $160{ }^{\circ} \mathrm{C}$; ramp $1.5{ }^{\circ} \mathrm{C} / \mathrm{min}$ to $270{ }^{\circ} \mathrm{C}$, with injector temperature maintained at 280 ${ }^{\circ} \mathrm{C}$. The carrier gas used was helium at a constant flow of $1 \mathrm{~mL} / \mathrm{min}$, and solutions were injected in split mode with a ratio of 10 . GC-MS analytical standards were purchased from Sigma-Aldrich (Menhaden:Capelin 1:1 fish oil; FAME Mix no. 47885-U). The GCMS results were given in relative area (percentage of 1 peak $=1$ FAME). Areas are calculated from raw data, and the ionization cross-section of each class of molecules was not taken into account. A blank sample (100\% solvent) was injected between each analysis to avoid carryover. FAMEs were identified using the mass spectral database (NIST, 2008) and diagnostic ions in mass spectra, with additional FAME identification based on the 
retention index (equivalent chain length: ECL). Two sets of analytical standards were injected to confirm the FAME identification. According to the international nomenclature, the position of the first double bond is given by the $(n-x)$ notation, by counting the number of carbon atoms from the methyl end (Revel et al., 2016). Each sample was injected in triplicate.

\section{Total protein and carbohydrate estimation}

Total protein was assessed by the Lowry method using bovine serum albumin (BSA) as standard instead of casein because of the greater similarity between the BSA amino acids composition and that of microalgae. Fifty mg of freeze-dried sample of each culture were manually ground with pestle and mortar in $4 \mathrm{~mL}$ distilled water and then centrifuged at $3000 \mathrm{rpm}$ for 10 minutes at room temperature. The Folin-Ciocalteu reactive (Sigma Co.) was diluted in two volumes of distilled water $(1: 2)$ and $0.5 \mathrm{~mL}$ of the diluted reactive was added to $1 \mathrm{~mL}$ of sample, previously mixed with $5 \mathrm{~mL}$ of the reactive " $\mathrm{C}$ " $[50$ volumes of reactive " $\mathrm{A}$ " $\left(2.0 \% \mathrm{Na}_{2} \mathrm{CO}_{3}+0.1 \mathrm{~N} \mathrm{NaOH}\right)+1$ volume of reactive "B" $\left(1 / 2\right.$ volume of $0.5 \% \mathrm{CuSO}_{4}$ $5 \mathrm{H} 2 \mathrm{O}+1 / 2$ volume of $1.0 \% \quad \mathrm{C}_{4} \mathrm{H}_{4} \mathrm{NaO}_{6}$ $\left.4 \mathrm{H}_{2} \mathrm{O}\right)$ ]. After the addition of each reactive, samples were stirred for $2 \mathrm{~s}$ in a test tube stirrer. Thirty minutes after the start of the chemical reaction at room temperature (time needed for colour development), spectrophotometric readings were achieved at $750 \mathrm{~nm}$ and compared BSA standards which ranged between 25 and $200 \mu \mathrm{gL}^{-1}$.

Carbohydrate concentrations were assessed by according to the phenol-sulphuric acid method (Dubois et al., 1956). To prepare the carbohydrate solution, $100 \mathrm{mg}$ of dry weight cyanobacteria sample were hydrolysed with $2.5 \mathrm{~N}$ chloridic acid for 1 hour at $100{ }^{\circ} \mathrm{C}$. A $0.2 \mathrm{ml}$ aliquot of this solution is mixed with $1 \mathrm{ml}$ of $5 \%$ aqueous solution of phenol (prepared immediately before use) in a test tube and then $5 \mathrm{~mL}$ of concentrated sulfuric acid were rapidly added to the mixture. After
10 minutes, the tubes are vortexed for 30 seconds and placed for 30 minutes in a water bath at room temperature for colour development. The samples were then analyzed at $490 \mathrm{~nm}$ using a spectrophotometer (Thermo Fisher Scientific, Massachusetts - USA) against control and compared with the standard glucose solution (concentration from 10 to $200 \mu \mathrm{g} \mathrm{mL}^{-1}$ ).

\section{Phycobiliproteins determination}

The quantification of phycobiliproteins (phycocyanin: PC, allophycocyanin: APC and phycoerythrin: PE) in the microalgal strain was carried out using the spectrophotometric method of (Bennett and Bogorod, 1973). After 5 minutes centrifugation of a $10 \mathrm{ml}$ volume of fresh cultures at $3000 \mathrm{rpm}$, the pellet was washed with buffer solution (1 M Tris- $\mathrm{Cl}$; $\mathrm{pH}=8.1$ ) and one volume of cell mass was subsequently re-suspended in five times of the volume of the same buffer. After that, continuous freezing at $-20{ }^{\circ} \mathrm{C}$ and thawing at $+4{ }^{\circ} \mathrm{C}$, and sonication ( 10 minutes with cycles of 30 seconds) were applied to all samples in order to allow the destruction of the microalgal cell walls. The cell fragments were then separated by centrifugation at $12000 \mathrm{rpm}$ for 10 minutes before taking the supernatant for spectrophotometric estimation of phycobiliproteins using the buffer as a blank. Absorbance measurements were performed at 620, 652 and $562 \mathrm{~nm}$ wavelengths using an UV - visible spectrophotometer (Heaios Y, Thermo Scientific; Massachusetts - USA). The amount of PC, APC and PE in the sample was calculated using the following formula (Bennett and Bogorod, 1973; Horvath et al., 2013):

$$
\begin{aligned}
& \mathrm{PC}[\mathrm{mg} / \mathrm{ml}]=\left(\mathrm{A}_{620}-0.474 \times \mathrm{x}_{652}\right) / 5.34 \\
& \mathrm{APC}[\mathrm{mg} / \mathrm{ml}]=\left(\mathrm{A}_{652}-0.208 \times \mathrm{A}_{620}\right) / 5.09 \\
& \mathrm{PE}[\mathrm{mg} / \mathrm{ml}]=\left(\mathrm{A}_{562}-2.41 \times \mathrm{xC}-\right. \\
& \text { 0.849xAPC }) / 9.62 \\
& \text { All experiments were done in }
\end{aligned}
$$
triplicates and the data are presented mean of three independent experiments with standard deviation. 
Table 1: Cyanobacterial strains isolated from Tunisian inland waters (river, lagoon, reservoir, spring water) with location and culture mediums.

\begin{tabular}{|c|c|c|c|c|c|}
\hline Order & Strain & & Sampling site & $\begin{array}{l}\text { Culture } \\
\text { medium }\end{array}$ & $\begin{array}{l}\text { Sampled and } \\
\text { isolated in }\end{array}$ \\
\hline Chroococcales & $\begin{array}{l}\text { Chroococcus } \\
\text { Chroo-CH }\end{array}$ & sp. & $\begin{array}{lr}\text { Chanchou } & \text { river } \\
\text { Lat }\left(33.540^{\circ}\right. & \mathrm{N}) \text {; } \\
\text { Long }\left(9.432^{\circ}\right. & \text { E) } \\
\text { S: 4.2 PSU } & \end{array}$ & BG11 & Present work \\
\hline \multirow{7}{*}{ Oscillatoriales } & $\begin{array}{l}\text { Arthrospira } \\
\text { platensis } \\
\text { Arthro-KB }\end{array}$ & & 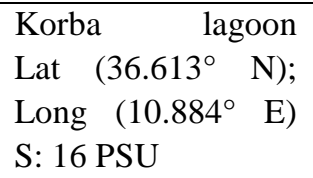 & BG11 & Present work \\
\hline & $\begin{array}{l}\text { Leptolyngbya } \\
\text { Osci-NB-01 }\end{array}$ & sp1. & 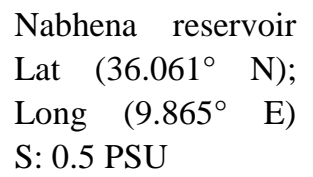 & BG11 & $\begin{array}{l}\text { Fathalli et al. } \\
\text { (2011) }\end{array}$ \\
\hline & $\begin{array}{l}\text { Leptolyngbya } \\
\text { Lepto-CH }\end{array}$ & sp2. & $\begin{array}{lr}\text { Chanchou } & \text { river } \\
\text { Lat }\left(33.540^{\circ}\right. & \mathrm{N}) \text {; } \\
\text { Long }\left(9.432^{\circ}\right. & \mathrm{E}) \\
\text { S: 4.2 PSU } & \end{array}$ & BG11 & Present work \\
\hline & $\begin{array}{l}\text { Limnothrix } \\
\text { Osci-BM-01 }\end{array}$ & sp. & 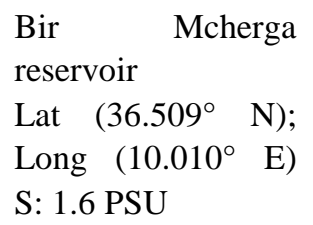 & BG11 & $\begin{array}{l}\text { Fathalli et al. } \\
\text { (2011) }\end{array}$ \\
\hline & $\begin{array}{l}\text { Planktothrix } \\
\text { agardhii } \\
\text { Plank-SS-01 }\end{array}$ & & 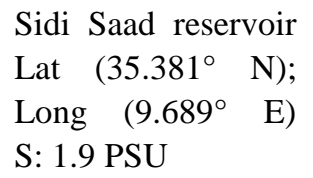 & BG11 & $\begin{array}{l}\text { Fathalli et al. } \\
\text { (2011) }\end{array}$ \\
\hline & $\begin{array}{l}\text { Spirulina } \\
\text { Spir-ML }\end{array}$ & sp. & $\begin{array}{lr}\text { Maltine } & \text { river } \\
\text { Lat }\left(34.245^{\circ}\right. & \mathrm{N}) \text {; } \\
\text { Long }\left(10.194^{\circ}\right. & \mathrm{E}) \\
\text { S: 45 PSU } & \end{array}$ & CONWAY & Present work \\
\hline & $\begin{array}{l}\text { Lyngbya } \\
\text { Lyng-ML }\end{array}$ & sp. & $\begin{array}{lr}\text { Maltine } & \text { river } \\
\text { Lat }\left(34.245^{\circ}\right. & \mathrm{N}) \text {; } \\
\text { Long }\left(10.194^{\circ}\right. & \mathrm{E}) \\
\text { S: 45 PSU } & \end{array}$ & CONWAY & Present work \\
\hline \multirow{2}{*}{ Nostocales } & $\begin{array}{l}\text { Anabaenopsis } \\
\text { circularis } \\
\text { Pseud-01 }\end{array}$ & & 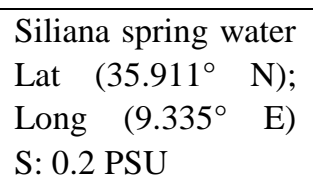 & BG11 & Present work \\
\hline & \multicolumn{2}{|c|}{$\begin{array}{l}\text { Cylindrospermopsis } \\
\text { raciborskii } \\
\text { Cyl-NB-05 }\end{array}$} & 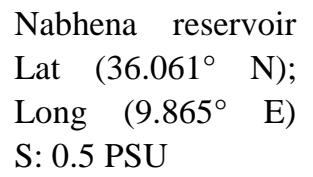 & BG11 & $\begin{array}{l}\text { Fathalli et al. } \\
\text { (2011) }\end{array}$ \\
\hline
\end{tabular}

S: Salinity; Lat: Latitude; Long: Longitude. 


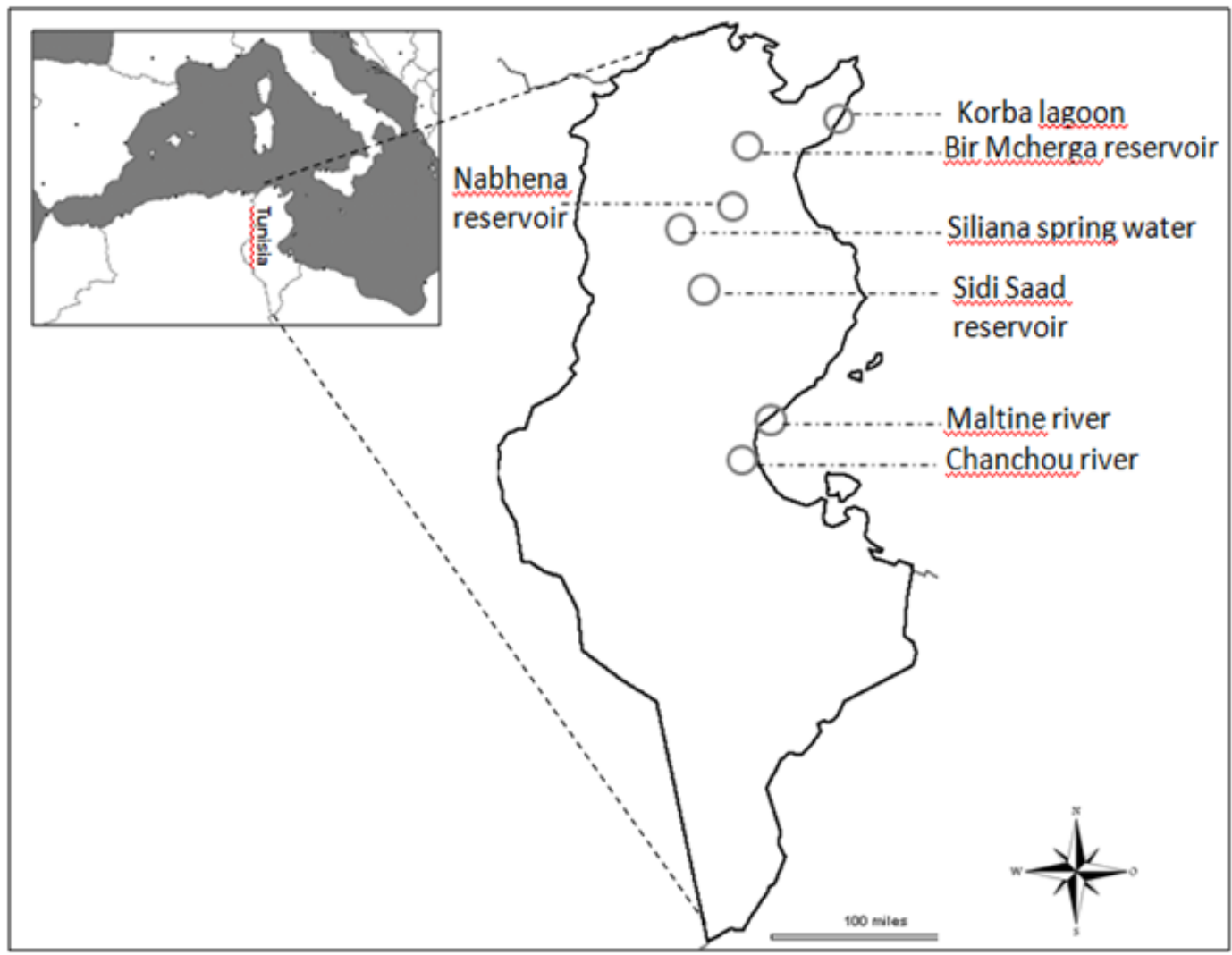

Figure 1: Map of Tunisia with sampling sites.

Table 2: Molecular identification of the cyanobacterial strains isolated from different Tunisian inland waters with $\%$ of similarity according to BLAST database and accession numbers of $16 \mathrm{~S}$ rRNA or rpoC1 sequences.

\begin{tabular}{lllll}
\hline \multirow{2}{*}{ Strain } & $\begin{array}{l}\text { Taxon according to } \\
\text { database }\end{array}$ & BLAST & \% of similarity & \multicolumn{2}{c}{ Accession numbers } \\
\cline { 4 - 5 } Osci-NB-01 & Leptolyngbya sp. & 99 & MG rRNA & rpoC1 \\
Osci-BM-01 & Limnotrix sp. & 100 & MG762091 & - \\
Plank-SS-01 & Planktothrix agardhii & 100 & MG762092 & - \\
Cyl-NB-05 & Cylindrospermopsis raciborskii & 96 & & HQ389355 \\
Pseud-01 & Anabaenopsis circularis & 99 & - & - \\
Arthro-KB & Arthrospira platensis & 100 & MG098078 & - \\
Lepto-CH & Leptolyngbya sp. & 99 & MG098079 & - \\
Spir-ML & Spirulina sp. & 99 & MG098077 & - \\
\hline
\end{tabular}




\section{RESULTS}

\section{Fatty acid profiles}

Results showed that the investigated strains produced 14 types of fatty acids, with carbon chains ranging from $\mathrm{C} 14$ to $\mathrm{C} 18$ with odd and even carbon numbers as well as different degrees of unsaturations (Table 3 ). The percentage of unidentified fatty acids was always under $1 \%$ for all strains, with the exception of Lepto-CH which showed $3 \%$ of unidentified fatty acids.

\section{Proteins and polysaccharides}

In the present study, the percentage of total protein ranged between 4 and $30 \%$ of DW (Figure 2). Apart from Osci-BM-01 and Cyl-NB-05, which presented a relatively good protein amount (about 30\% of DW each), the other strains exhibited lesser percentages, reaching a minimum of less than 5\% DW in Chroo-CH.

As regards to total polysaccharides, the majority of the strains exhibited low carbohydrate contents (less than $6 \mathrm{mg} / \mathrm{ml}$ or $30 \%$ DW) (Figure 3). The only strains presenting a relatively high total carbohydrate content exceeding $6 \mathrm{mg} / \mathrm{ml}$ or $30 \%$ of DW were Lepto-CH, Cyl-NB-05, and Chroo-CH (9.3; 6.6 and $6.1 \mathrm{mg} / \mathrm{ml}$ or $46.6 ; 33.3$ and $30.6 \%$ DW, respectively).

\section{Phycobiliproteins}

Quantitative evaluation of PC, APC, and PE content was performed in all investigated microalgal strains; the results are displayed in Figure 4. Among all the essayed isolates, Cyl-NB-05 contained maximum total phycobiliprotein content, exceeding 3150 $\mu \mathrm{g} / \mathrm{ml}$ of fresh culture. Interestingly, the PC level in this Nostocales cyanobacterium occurs at more than ten-folds higher than in the other two phycobiliprotein groups taken together $(2873 \mu \mathrm{g} / \mathrm{ml}$ of PC against $277 \mu \mathrm{g} / \mathrm{ml}$ for APC and PE combined) and at more than two-folds higher compared with the PC level in all the other 10 strains. Significantly smaller amounts of PC were found in the other tested strains which were in the range between 11 (Pseud-01) and $671 \mu \mathrm{g} / \mathrm{ml}$ (PlankSS-01). In terms of APC production, the maximum yield was found in the two Oscillatoriales cyanobacterium strains OsciNB-01 and Plank-SS-01 (362 and $326 \mu \mathrm{g} / \mathrm{ml}$, respectively), while PE was present at lower quantities comparing with the other two constituents (between 20 and $126 \mu \mathrm{g} / \mathrm{ml}$ ) in the investigated strains, except for Chroo- $\mathrm{CH}$ and Pseud-01, where it was the major phycobiliprotein produced.

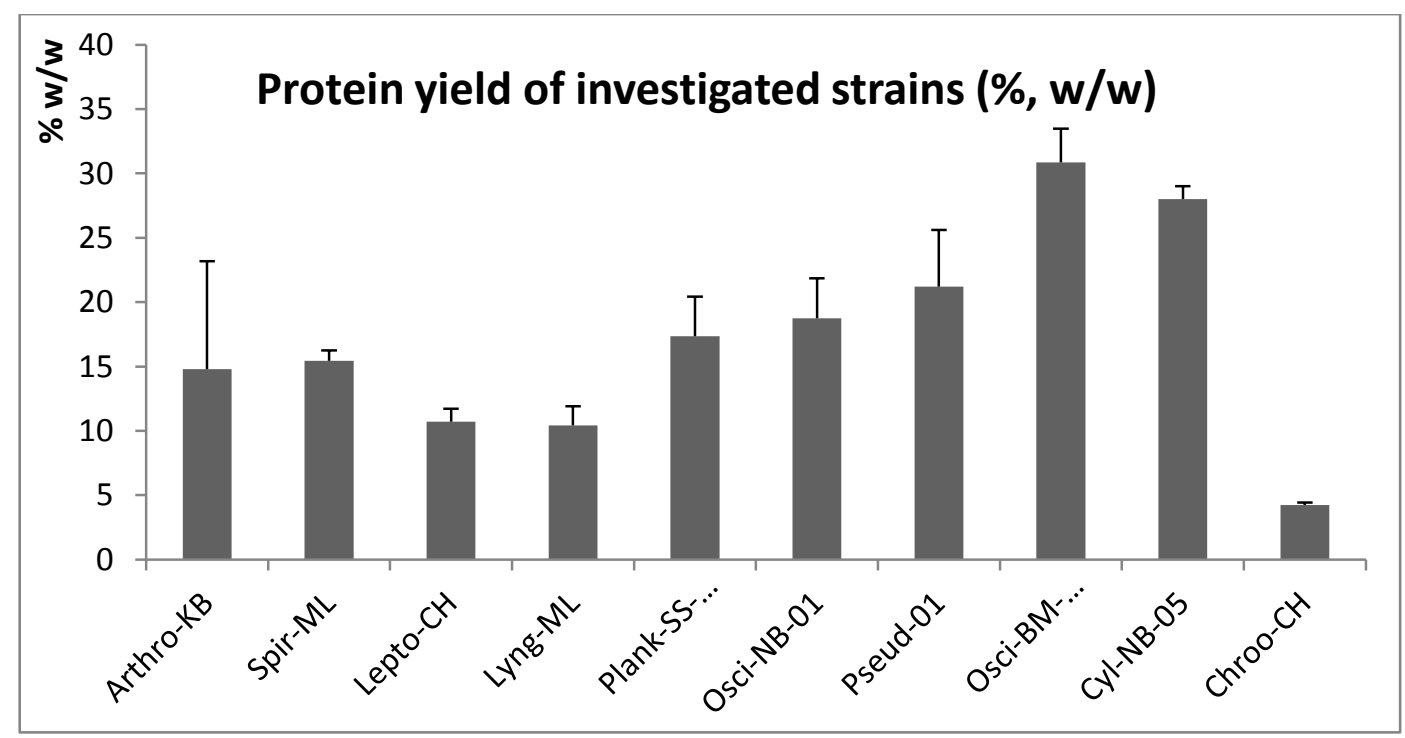

Figure 2: Total protein yields of cyanobacterial strains isolated from different aquatic habitats expressed in $\%$ of dry weight. Bars indicate the standard deviation of three replicates. 




Figure 3: Total carbohydrate content of cyanobacterial strains isolated from different aquatic habitats expressed in $\%$ of dry weight. Bars indicate the standard deviation of three replicates.

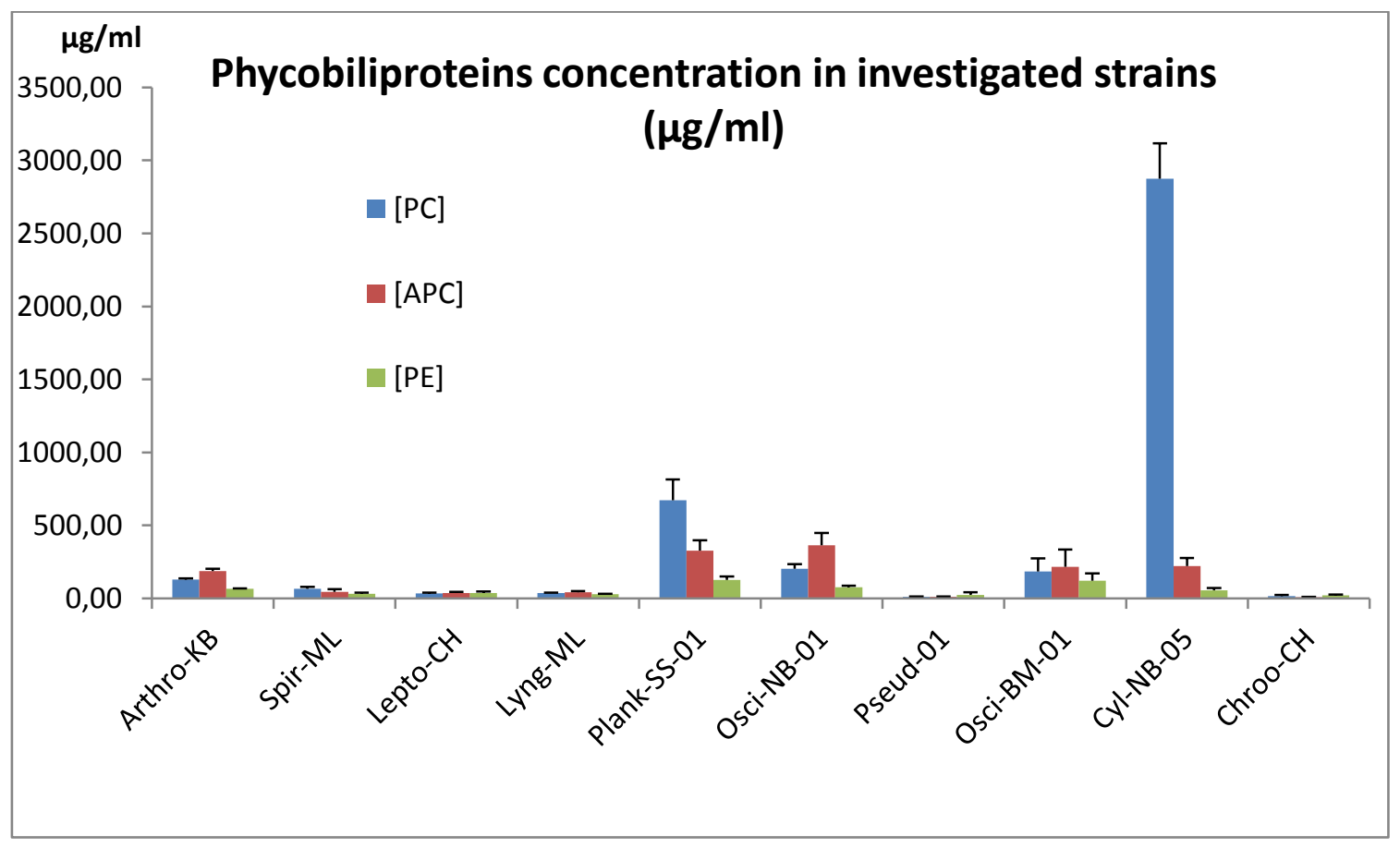

Figure 4: Phycobiliproteins concentration of microalgal strains isolated from different aquatic habitats expressed in $\mu \mathrm{g}$ per $\mathrm{ml}$ of fresh culture. Bars indicate the standard deviation of three replicates $(\mathrm{PC}=$ Phycocyanin $; \mathrm{APC}=$ Allophycocyanin $; \mathrm{PE}=$ Phycoerythrin $)$. 


\section{K. GHARBI et al. / Int. J. Biol. Chem. Sci. 13(4): 2286-2300, 2019}

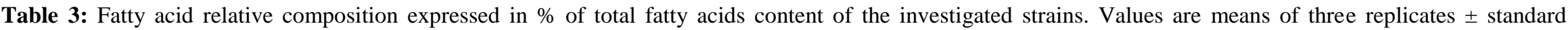
deviation.

\begin{tabular}{|c|c|c|c|c|c|c|c|c|}
\hline Fatty acids & Arthro-KB & Osci-NB-01 & Lepto-CH & Lyng-ML & Osci-BM-01 & Plank-SS-01 & Spir-ML & Chroo-CH \\
\hline C14:0 & nd & nd & nd & $0.62 \pm 0.2$ & $22.89 \pm 2.5$ & nd & $25.98 \pm 2.5$ & nd \\
\hline C15:0 & nd & $0.39 \pm 0.1$ & $1 \pm 0.1$ & $0.68 \pm 0.2$ & nd & $0.75 \pm 0.1$ & $1.23 \pm 0.0$ & nd \\
\hline C16:0 & $48.83 \pm 4.5$ & $29.56 \pm 3.6$ & $26.68 \pm 5.1$ & $38.08 \pm 1.5$ & $23.34 \pm 0.9$ & $32.42 \pm 4.9$ & $20.2 \pm 1.9$ & $60.79 \pm 5.6$ \\
\hline C17:0 & nd & $0.84 \pm 0.3$ & nd & nd & nd & nd & nd & nd \\
\hline C18:0 & nd & $1.26 \pm 0.3$ & $2.61 \pm 0.5$ & $1.57 \pm 0.2$ & nd & $2.56 \pm 0.9$ & $1.26 \pm 0.4$ & $1.04 \pm 0.2$ \\
\hline$\Sigma$ Saturated & $48.83 \pm 4.5$ & $32.05 \pm 4.5$ & $30.29 \pm 5.6$ & $40.95 \pm 0.9$ & $46.24 \pm 2.03$ & $35.74 \pm 5.9$ & $48.69 \pm 1.1$ & $61.83 \pm 5.5$ \\
\hline C14:1 & nd & nd & nd & nd & $17.02 \pm 1.0$ & nd & nd & nd \\
\hline C16:1 (n-7) & $3.62 \pm 0.7$ & $25.27 \pm 3.4$ & $3.2 \pm 0.2$ & $44.54 \pm 3.4$ & $19.76 \pm 0.6$ & $21.84 \pm 0.9$ & $48.84 \pm 1.3$ & $10.09 \pm 0.7$ \\
\hline C16:1 (n-5) & nd & nd & nd & nd & $12.55 \pm 0.3$ & nd & nd & $3.61 \pm 0.5$ \\
\hline C16:1 (n-3) & nd & nd & $19.67 \pm 1.0$ & nd & nd & nd & nd & nd \\
\hline $\mathrm{C} 17: 1$ & $0.12 \pm 0.04$ & $0.54 \pm 0.1$ & nd & nd & nd & nd & nd & nd \\
\hline C18:1 (n-9) & nd & $23.32 \pm 6.7$ & $21.41 \pm 3.3$ & $0.65 \pm 0.3$ & $4.41 \pm 1.1$ & $20.32 \pm 3.5$ & $0.85 \pm 0.1$ & $4.5 \pm 3.2$ \\
\hline $\mathrm{C} 18: 1(\mathrm{n}-7)$ & nd & $4.03 \pm 1.7$ & $7.11 \pm 1.0$ & $2.33 \pm 0.7$ & nd & $4.55 \pm 2.3$ & $1.61 \pm 0.1$ & $1.85 \pm 0.6$ \\
\hline C18:1 (n-6) & nd & nd & $1.36 \pm 0.3$ & nd & nd & nd & nd & nd \\
\hline$\Sigma$ MUFA & $3.74 \pm 0.4$ & $53.17 \pm 1.4$ & $52.75 \pm 2.7$ & $47.52 \pm 2.7$ & $53.76 \pm 2.03$ & $46.72 \pm 2.7$ & $51.3 \pm 1.1$ & $20.06 \pm 2.6$ \\
\hline C14:2 & nd & nd & nd & nd & nd & nd & nd & $7.05 \pm 0.5$ \\
\hline C16:2 & nd & $0.95 \pm 0.1$ & nd & $11.11 \pm 2.5$ & nd & nd & nd & $3.43 \pm 0.9$ \\
\hline C18:2 (n-6) & $19.91 \pm 2.5$ & $13.81 \pm 3.0$ & $13.92 \pm 3.1$ & nd & nd & $17.53 \pm 4.5$ & nd & $1.02 \pm 0.6$ \\
\hline $\mathrm{C} 16: 3$ & nd & nd & nd & nd & nd & nd & nd & $6.59 \pm 1.8$ \\
\hline C18:3 & $26.84 \pm 3.2$ & nd & nd & nd & nd & nd & nd & nd \\
\hline$\Sigma$ PUFA & $46.75 \pm 3.1$ & $14.76 \pm 2.9$ & $13.92 \pm 3.1$ & $11.11 \pm 2.5$ & nd & $17.53 \pm 4.5$ & nd & $18.1 \pm 2.9$ \\
\hline PUFA/MUFA & $12.5 \pm 1.6$ & $0.27 \pm 0.04$ & $0.26 \pm 0.04$ & $0.23 \pm 0.06$ & nd & $0.37 \pm 0.09$ & nd & $0.9 \pm 0.02$ \\
\hline
\end{tabular}

nd $=$ not detected 


\section{DISCUSSION}

\section{Fatty acid composition}

As can be seen in Table 3, the cyanobacterium Arthro-KB can be distinguished from all other strains as it was the only producer of linolenic acid, (C18:3) with a percentage exceeding $25 \%$, which approached the results reported by many authors working on A. platensis, such as Xue et al. (2002). From a pharmaceutical point of view, producing important amounts of linolenic acid is of particular interest since several findings reported on the antimicrobial activity of this tri-unsaturated fatty acid, particularly against a group of pathogenic germs, such as Staphylococcus aureus, Candida albicans, and Aspergillus niger (Xue et al., 2002; Herrero et al., 2006).

Moreover, the percentages of the major fatty acids in Arthro-KB found in this study were in accordance with those in previous works (Xue et al., 2002; Colla et al., 2004), indicating that $A$. platensis was characterized by a fatty acid profile dominated mainly by palmitic (C16:0), linoleic (C18:2), and linolenic acid (C18:3) and that fatty acids with longer chains (> 20 carbons) were almost not detected. This profile represents a remarkable added-value to the therapeutic potential of this strain since linoleic acid (about 20\%) is additionally efficient against human pathogens and also against some aquatic pathogenic bacteria, even at relatively low concentrations (Benkendorff et al., 2005).

As regards to oleic acid (C18:1), it was recorded in all strains, with the exception of Arthro-KB. However, only three strains, namely Plank-SS-01, Lepto-CH and Osci-NB01 , contained a high percentage of oleic acid (25\%, $28 \%$, and $27 \%$, respectively). Several studies on this monounsaturated acid have demonstrated its powerful antioxidant effect (Ceron et al., 2007) and its anti-platelets aggregation property (Xu et al., 2018), the acid thus presenting a promising potential as an accessible and safe alternative to synthetic molecules. In addition, Harada et al. (2000) demonstrated the larvicidal activity of this fatty acid extracted from $P$. agardhii, especially against mosquito larvae. The latter functionality gives the top oleic acid producer strains characterized in the present work (Plank-SS-01, Lepto-CH, and Osci-NB-01) even more valuable potential as they can be used as natural sources of insecticides that are both effective and environmentally friendly.

Otherwise, palmitoleic acid (C16:1) was found in our study at significant percentages in Plank-SS-01, Osci-NB-01, Lepto-CH, and Osci-BM-01 (between 20 and $30 \%$ of total fatty acid content) and ultimately even in a much higher amount in Spir-ML (about 50\%) and Lyng-ML (around 45\%). Many authors reported the remarkable and significant bacteriolytic activity of palmitoleic acid-even at relatively low concentrationsagainst human pathogens and aquatic pathogenic bacteria as well as its ability to reduce the risk of certain heart diseases (Benkendorff et al., 2005; Plaza et al., 2009). Interestingly, among all these strains that are particularly rich in palmitoleic acid, only Lepto-CH appeared to produce omega-3 fatty acids (around $85 \%$ of total amount of palmitoleic acid) which are widely known for their protective role against diabetes, rheumatoid arthritis, rheumatism, skin diseases, digestive and metabolic diseases, neuro-cognitive disorders, and colorectal cancer (Shahidi and Ambigaipalan, 2018).

\section{Proteins and polysaccharides content}

Compared to the present study, higher protein amounts determined with the same analyzing method have been reported from an Indian strain of $C$. turgidus (Chinnu et al., 2014) and A. platensis (Lopez et al., 2010). We infer that the differences are probably due-apart from the strain effect-to the variations in culture conditions, such as the level of illumination (18:6 versus 12:12 light:dark cycle), the availability of nutrients (BG11 medium versus CFTRI and Zarrouk's medium), the culture technique (Batch versus continuous culture), or the growth phase. Indeed, these various culture conditions can lead to differences in protein production levels and can affect the quantity and quality of microalgal biochemical composition (Lopez et al., 2010; Salama et al., 2013). 
In the present study, the two non-toxic cyanobacteria strains Osci-BM-01 and CylNB-05 (Fathalli et al., 2011) showed a remarkably high protein productivity, thus representing excellent candidates to be valued in fast growing markets, such as animal feed and aquaculture. Furthermore, our protein best producing strains might be exploited beyond their nutritional values in several other interesting applications, such as nutraceuticals (Chacon-Lee and Gonzalez-Marino, 2010), cosmeceuticals (Sekar and Chandramohan, 2008), and pharmaceuticals (Samarakoon and Jeon, 2012).

In relation to total polysaccharides analyzed in the present work in terms of total sugars, results showed that most strains displayed relatively modest carbohydrate amounts, not exceeding $6 \mathrm{mg} / \mathrm{ml}$. The lowest amount was found in Arthro-KB $(2 \mathrm{mg} / \mathrm{ml}$ or $10.3 \%$ DW), which is in agreement with Becker (2007), who reported a similar value (11\% DW) for this species.

On the other hand, it can be seen that the oscillatoriales strain Lepto-CH was most productive of total carbohydrates due probably to the presence of a thick mucilaginous sheath covering its single trichome which is clearly visible under the microscope. Indeed, this mucilaginous sheath with high contents in pectic acids and acid mucopolysaccharides was also reported by Mandal et al. (2011). Moreover, some authors were able to induce an increase in the thickness of the mucilaginous sheath layer of some cyanobacterial species (for example the Indian strain Lyngbya majuscula) and consequently to improve the carbohydrate productivity by applying stressing culture conditions, such as prolonged exposure to UV-B dose (Mandal et al., 2011).

\section{Phycobiliproteins}

According to our results, the
Cylindrospermopsis strain Cylind-NB
occupies an outstanding position among all
investigated isolates by being by far the most
productive of total phycobiliproteins, with a
total amount exceeding $3000 \mu \mathrm{g} / \mathrm{ml}$. With
regard to PC, and_compared to results reported by other authors, the Cylindrospermopsis strain essayed in the present study appears to be an extraordinarily rich source of this valuable pigment-protein complex. For instance, a much lower PC amount (about 5 $\mu \mathrm{g} / \mathrm{ml}$ ) in a Cylindrospermopsis raciborskii strain isolated from surface water samples of Lake Balaton (Hungary), using the same extraction technique (repeated cycles of freezing and thawing combined with sonication), was reported by Horvath et al. (2013).

Aside from the strain effect-which may be the main factor explaining the huge difference observed between the two isolates - other factors may also have intervened, especially the high light intensity $\left(40 \mu \mathrm{mol} \mathrm{m} \mathrm{m}^{-2} \mathrm{~s}^{-1}\right)$ applied in Horvath et al. (2013) compared to the present work $(27 \mu \mathrm{mol}$ $\left.\mathrm{m}^{-2} \mathrm{~s}^{-1}\right)$. In fact, the negative effect of applied light intensities of more than $25 \mu \mathrm{mol} \mathrm{m} \mathrm{s}^{-2} \mathrm{~s}^{-1}$ on the PC production by cyanobacterial isolates was highlighted in several studies. For instance, De Oliveira et al. (2014) reported that the level of incident light is indeed one of the factors that most influence the cyanobacteria metabolism and that lower light intensities were more advantageous in terms of total phycobiliprotein yields produced by two isolates of edaphic algae from the genus Nostoc. The authors suggested that when the light availability increased, the content of these pigments decreased as a strategy for prevention of photo-oxidative damage caused by the production of free radicals.

With such an exceptional PC productivity, the Cylindrospermopsis isolate investigated in the present study may indeed be considered as a superrich natural source of this highly valuable phycobiliprotein group which had been proved to possess numerous potent bioactivities with extremely health beneficial effects. Among the most interesting therapeutic and nutritional functions attributed to this natural, non-toxic substance that are especially sought for food and pharmaceutical industry is the antioxidant and radical scavenging activities (Samarakoon and Jeon, 2012). In fact, several synthetic commercial antioxidants, such as butylated hydroxyanisole 
(BHA), butylated hydroxytoluene (BHT), tertbutylhydroquinone (TBHQ), and propyl gallate (PG) have been used widely to retard the oxidation and peroxidation processes. However, the use of these synthetic antioxidants is often associated with potential health hazards, making the search for natural antioxidants as safe alternatives in food and pharmaceutical industry even more appealing and urgent. Furthermore, it had been shown that the protective action of antioxidants may be valued on many levels. Firstly and most importantly, they have a positive effect on human health as they can protect the human body against damage by ROS (Reactive Oxygen Species) which attack macromolecules, such as membrane lipids, proteins, and DNA, leading to many health disorders, such as cancer, diabetes mellitus, aging, and neurodegenerative diseases. In addition, antioxidants can prevent food deterioration caused by lipid oxidation as well as the formation of undesirable secondary lipid peroxidation products by ROS, such as superoxide anion, hydroxyl radicals, and $\mathrm{H}_{2} \mathrm{O}_{2}$ which are known to be responsible for the decrease in the nutritional value of lipid foods hence affecting their safety and appearance (Pangestuti and Kim, 2011).

Some other studies also reported the effectiveness of $\mathrm{PC}$ as a proliferation inhibitor of cancer cells in vivo and in vitro. For example, Liu et al. (2000) reported the capacity of PC extracted from Spirulina platensis to significantly inhibit the growth of human chronic myelogenous leukemiablastcrisis K562 cells in a dose-dependent manner.

In addition, several epidemiological studies highlighted another very interesting therapeutic property of PC that may open very promising perspectives in the medical field, especially in the treatment of oxidative stressinduced neuronal injuries. For instance, the neuroprotective role of PC against cell death caused by $24 \mathrm{~h}$ potassium and serum $(\mathrm{K} / \mathrm{S})$ withdrawal in rat cerebellar granule cell (CGC) cultures was demonstrated by Rimbau et al. (2001).
Taken together, the PC super rich strain characterized in the present work, Cylind-NB, may be of particular interest in this field since it can be considered as a natural reservoir of effective and non-toxic drugs to be used in the fight against some of the most common neurodegenerative diseases, such as Alzheimer's and Parkinson's.

\section{Conclusion}

The extracts from the cyanobacterial strains, analyzed in the present study, represent a natural and available source of proteins and of some highly valuable fatty acids. Thus, the nutritional and functional complements provided by these extracts, particularly those from the Oscillatoriales strains Plank-SS-01, Arthro-KB, and Lepto$\mathrm{CH}$, can be used in the prevention of infectious diseases and of cardiovascular and coronary disorders and even as effective and environmentally friendly insecticides. Meanwhile, the Cylindrospermopsis raciborskii strain, Cyl-NB-05, characterized in the present study appears to be of huge and exceptional potential to be valued in therapeutic and medical sectors due to its extraordinary production and accumulation capacity of phycocyanin. Finally, we suggest that further studies be carried out on the produced protein's quality and especially on the absence of potential toxicity for human and animal consumption. The strains themselves, their cultivation conditions, as well as the extraction and purification methods remain important basic elements to be taken into account in the biological activities sought.

\section{COMPETING INTERESTS}

The authors declare that they have no competing interests.

\section{AUTHORS' CONTRIBUTIONS}

KG designed and performed the experiments, derived the models and analysed the data. AF and CF contributed to sample preparation and verification of the analytical methods, as well as the interpretation of the results, especially with regard to the molecular 
identification section. ABRJ and MSR supervised the project, helped conceiving the original idea, provided critical feedback and contributed in the shaping of the research, analysis and manuscript. All authors discussed the results and contributed to the final manuscript.

\section{ACKNOWLEDGMENTS}

This study has been supported by U.R. Ecosystèmes et Ressources Aquatiques, Institut National Agronomique de Tunisie, University of Carthage and laboratory of Bioactive Molecules, University of Nice Sophia Antipolis, which are greatly acknowledged. This research was also financially supported by the Ministry of Higher Education and Scientific Research of the Tunisian government.

\section{REFERENCES}

Becker EW. 2007. Micro-algae as a source of protein. Biotechnol. Adv., 25(2): 207210.

DOI: http://dx.doi.org/10.1016/j.biotechadv.20 06.11 .002

Benkendorff K, Davis AR, Rogers CN, Bremner JB. 2005. Free fatty acids and sterols in the benthic spawn of aquatic molluscs, and their associated antimicrobial properties. J. Exp. Mar. Biol. Ecol., 316(1): 29-44. DOI: http://dx.doi.org/10.1016/j.jembe.2004.1 0.001

Bennett A, Bogorod L. 1973. Complementary chromatic adaptation in filamentous blue-green alga. J. Cell Biol., 58(2): 419-435.

DOI: http://dx.doi.org/10.1083/jcb.58.2.419

Blancheton A. 1985. Production d'Algues unicellulaires. Ifremer report, Ifremer Bibliothèque de PALAVAS, 26 p.

Bligh EG, Dyer WJ. 1959. A rapid method of total lipid extraction and purification. Can. J. Biochem. Physiol., 37(8): 911917. DOI: http://dx.doi.org/10.1139/o59099

Ceron MC, García-Malea MC, Rivas J, Acien FG, Fernandez JM, Del Río E, Guerrero MG, Molina E. 2007. Antioxidant activity of Haematococcus pluvialis cells grown in continuous culture as a function of their carotenoid and fatty acid content. Appl. Microbiol. Biotechnol., 74(5): 1112-1119. DOI: http://dx.doi.org/10.1007/s00253-0060743-5

Chacon-Lee TL, Gonzalez-Marino GE. 2010. Microalgae for "health" foods Possibilities and challenges. Compr. Rev. Food Sci. Food Saf., 9(6): 655-675. DOI: http://dx.doi.org/10.1111/j.15414337.2010.00132.x

Chinnu K, Muthukumaran M, Mukund S, Sivasubramanian V. 2014. Studies on value added bio-chemicals of Chroococcus turgidus. Int. J. Instit. Pharm. Life Sci., 4: 75-92.

Colla LM, Bertolin TE, Costa JA. 2004. Fatty acids profile of Spirulina platensis grown under different temperatures and Nitrogen concentrations. Z. Naturforsch C., 59: 55-59. DOI: https://dx.doi.org/10.1515/znc-2004-1212

De Oliveira CA, Oliveira WC, Ribeiro SMR, Stringheta PC, Nascimento AG. 2014. Effect of light intensity on the production of pigments in Nostoc spp. Eur. J. Biol. Med. Sci. Res., 2(1): 23-36.

Dubois M, Gilles KA, Hamilton JK, Rebers PA, Smith F. 1956. Colorimetric Method for Determination of Sugars and Related Substances. Anal. Chem., 28(3): 350$356 . \quad$ DOI: https://dx.doi.org/10.1021/ac60111a017

Fathalli A, Jenhani AB, Moreira C, Welker M, Romdhane M, Antunes A, Vasconcelos V. 2011. Molecular and phylogenetic characterization of potentially toxic cyanobacteria in Tunisian freshwaters. Syst. Appl. Microbiol., 34(4): 303-310. DOI:

https://dx.doi.org/10.1016/j.syapm.2010. 12.003

Harada K, Suomalainen M, Uchida H, Masui H, Ohmura K, Kiviranta J, Niku-Paavola ML, Ikemoto T. 2000. Insecticidal Compounds Against Mosquito Larvae from Oscillatoria agardhii Strain 27. 
John Wiley and Sons, Inc. Environ.

Toxicol., 15(2): 114-119. DOI: https://dx.doi.org/10.1002/(SICI)15227278(2000)15:2<114::AIDTOX7>3.0.CO;2-P

Herrero M, Ibañez E, Cifuentes A, Reglero G, Santoyo S. 2006. Dunaliella salina microalga pressurized liquid extracts as potential antimicrobials. J. Food Protein., 69(10): 2471-2477. DOI: https://dx.doi.org/10.4315/0362-028x69.10.2471

Horvath H, Kovács AW, Riddick CAL, Présing M. 2013. Extraction methods for phycocyanin determination in freshwater filamentous cyanobacteria and their application in a shallow lake. Eur. J. Phycol., 48(3): 278-286. DOI: https://dx.doi.org/10.1080/09670262.201 3.821525

Jalal KCA, Shamsuddin AA, Rahman MF, Nurzatul NZ, Rozihan M. 2013. Growth and Total Carotenoid, Chlorophyll a and Chlorophyll b of Tropical Microalgae (Isochrysis sp.) in Laboratory Cultured Conditions. J. Biol. Sci., 13(1): 10-17. DOI:

https://dx.doi.org/10.3923/jbs.2013.10.1 7

Kata FS, Athbi AM, Manwar EQ, Al-Ashoor A, Abdel-Daim M, Aleya L. 2018. Therapeutic effect of alkaloid extract of the cyanobacteria Spirulina platensis on lipid profile in hypercholesterolemic male rabbits. Environ. Sci. Pollut. Res. Int., 25(20): 19635-19642. DOI: http://dx.doi.org/10.1007/s11356-0182170-4

Liu Y, Xu L, Cheng N, Lin L, Zhang C. 2000. Inhibitory effect of phycocyanin from Spirulina platensis on the growth of human leukemia K562 cells. J. Appl. Phycol., 12(2): 125-130. DOI: http://dx.doi.org/10.1023/A:1008132210 772

Lopez CVG, García MCC, Fernández FGA, Bustos CS, Chisti Y, Sevilla JMF. 2010. Protein measurements of microalgal and cyanobacterial biomass. Bioresour. Technol., 101(19): 7587-7591. DOI: http://dx.doi.org/10.1016/j.biortech.2010 .04 .077

Mandal S, Rath J, Adhikary SP. 2011. Adaptation strategies of the sheathed cyanobacterium Lyngbya majuscula to ultraviolet-B. J. Photochem. Photobiol. B Biol., 102(2):115-122. DOI: http://dx.doi.org/10.1016/j.jphotobiol.20 10.09.011

Morrison WR, Smith LM. 1964. Preparation of fatty acid methyl esters and dimethylacetals from lipids with boron fluoride-methanol. J. Lipid. Res., 5: 600-608.

Moscoso JLG, Obeid W, Kumar S, Hatcher PG. 2013. Flash hydrolysis of microalgae (Scenedesmus sp.) for protein extractionand production of biofuels intermediates. J. Supercritical. Fluids., 82: $\quad$ 183-190. DOI: http://dx.doi.org/10.1016/j.supflu.2013.0 7.012

M'baye BK, Lo B, Bassene E. 2011. Etude quantitative de quelques pigments de la Spiruline cultivée en Mauritanie en vue d'une valorisation nutritionnelle. Int. J. Biol. Chem. Sci., 5(5): 2035-2038. DOI: http://dx.doi.org /10.4314/ijbcs.v5i5.24

Pangestuti R, Kim S. 2011. Biological activities and health benefit effects of natural pigments derived from marine algae. J. Funct. Foods., 3(4): 255-266. DOI:

http://dx.doi.org/10.1016/j.jff.2011.07.00 1

Plaza M, Herrero M, Cifuentes A, Ibáñez E. 2009. Innovative Natural Functional Ingredients from Microalgae. J. Agric. Food Chem., 57(16): 7159-7170. DOI: http://dx.doi.org/10.1021/jf901070g

Revel J, Massi L, Mehiri M, Boutoute M, Mayzaud P, Capron L, Sabourault C. 2016. Differential distribution of lipids in epidermis, gastrodermis and hosted Symbiodinium in the sea anemone Anemonia viridis. Comp. Biochem. Physiol. A Comp. Physiol., 191: 140$151 . \quad$ DOI: http://dx.doi.org/10.1016/j.cbpa.2015.10. 017 
Rimbau V, Camins A, Pubill D, Sureda FX, Romay C, González R, Jiménez A, Escubedo E, Camarasa J, Pallàs M. 2001. C-phycocyanin protects cerebellar granule cells from low potassium/serum deprivation-induced apoptosis. Naunyn. Schmiedebergs. Arch. Pharmacol., 364(2): 96-104. DOI: http://dx.doi.org/10.1007/s00210010043 7.

Rippka R, Deruelles J, Waterbury JB, Herdman M, Stanier RY. 1979. Genetic assignments, strains histories and properties of pure cultures of cyanobacteria. J. Gen. Microbiol., 111(1): 1-61. DOI: http://dx.doi.org/10.1099/00221287-111$1-1$.

Salama ES, Kim HC, Abou-Shanab RAI, Ji MK, Oh YK, Kim SH, Jeon BH. 2013. Biomass, lipid content, and fatty acid composition of freshwater Chlamydomonas mexicana and Scenedesmus obliquus grown under salt stress. Bioprocess Biosyst. Eng., 36(6): 827-833.

DOI: http://dx.doi.org/10.1007/s00449-0130919-1.

Samarakoon K, Jeon Y. 2012. Biofunctionalities of proteins derived from marine algae - A review. Food Res. Int., 48(2): $\quad 948-960 . \quad$ DOI: http://dx.doi.org/10.1016/j.foodres.2012. 03.013 .

Sekar S, Chandramohan M. 2008. Phycobiliprotein as commodity: Trends in applied research, patents and commercialization. J. Appl. Phycol.,
20(2): $\quad$ 113-136. $\quad$ DOI: http://dx.doi.org/10.1007/s10811-0079188-1.

Shahidi F, Ambigaipalan P. 2018. Omega-3 Polyunsaturated Fatty Acids and Their Health Benefits. Annu. Rev. Food. Sci. Technol., 9: 345-381. DOI: http://dx.doi.org/10.1146/annu- revfood-111317-095850.

Trabelsi L, Mnari A, Abdel-Daim MM, AbidEssafi S, Aleya L. 2016. Therapeutic properties in Tunisian hot springs: first evidence of phenolic compounds in the cyanobacterium Leptolyngbya sp. biomass, capsular polysaccharides and releasing polysaccharides. $B M C$ Complement Altern. Med., 16: 515. DOI: http://dx.doi.org/10.1186/s12906-0161492-3.

Xu XR, Wang Y, Adili R, Ju L, Spring CM, Jin JW, Yang H, Neves MAD. 2018. Apolipoprotein A-542 IV binds $\alpha \operatorname{IIb} \beta 3$ integrin and inhibits thrombosis. Nature Communications, 9(1): 3608. DOI: http://dx.doi.org/10.1038/s41467-01805806-0.

Xue C, Hu Y, Saito H, Zhang Z, Li Z, Cai Y, Ou C, Lin H, Imbs AB. 2002. Molecular species composition of glycolipids from Spirulina platensis. Food Chem., 77(1): 9-13.

DOI: http://dx.doi.org/10.1016/S03088146(01)00315-6. 